Chirurgia (2020) 115: 756-766

No. 6, November - December

Copyright@ Celsius

http://dx.doi.org/10.21614/chirurgia.115.6.756

\title{
Is Specialisation Needed in Laparoscopic Cholecystectomy? A Retrospective Cohort Study of 5122 Patients
}

\author{
Abdulzahra Hussain ${ }^{1,2^{*}}$, Guillaume Lafaurie $^{3}$, Rhehana Hafeez ${ }^{3}$, Shamsi El-Hasani ${ }^{3}$ \\ ${ }^{1}$ General Surgery Department, Doncaster and Bassetlaw Teaching Hospitals, Doncaster, United Kingdom \\ ${ }^{2}$ Sheffiled University, Sheffield, United Kingdom \\ ${ }^{3}$ General Surgery Department, Kings College Hospitals, London, United Kingdom
}

*Corresponding author: Abdulzahra Hussain FRCS, FEBS Upper Gl consultant surgeon Doncaster and Bassetlaw Teaching Hospitals, Sheffiled University Sheffield, United Kingdom Email: azahrahussain@yahoo.com

\section{Abbreviations:}

LC - laparoscopic cholecystectomy; UGI - upper gastrointestinal:

CBD - common bile duct; GB - gallbladder;

HPB - hepatopancreatic biliary;

OG - oesophago-gastric;

LGI - lower gastrointestinal; ERCP - endoscopic retrograde cholangiopancreatography; OC - open cholecystectomy; $\mathrm{RR}$ - relative risk; ARR - absolute risk reduction.

Received: 12.07 .2020 Accepted: 08.09.2020

\section{Rezumat}

Este necesară specializarea în colecistectomia laparoscopică? Un studiu retrospectiv de cohortă си 5122 pacienți

Context:Litiaza biliară este o problemă comună, iar colecistectomia laparoscopică (CL) este o intervenție chirurgicală electivă comună. Intervenția a fost efectuată de un chirurg generalist şi chirurgi specializati în chirurgie colonorectală, mamară şi vasculară, conform studiului de evaluare pe scara cea mai largă din Regatul Unit (studiul CholeS).

Obiective: Compararea rezultatelor colecistectomiei laparoscopice efectuate de un chirurg specialist în chirurgie a tractului gastrointestinal superior (TGS) cu cele din studiul CholeS şi alte studii internaționale pe scară largă. Ipoteza noastră: Specialiştii TGS au rezultate mai bune în cazul pacienților de CL.

Metode: Au fost incluşi toți pacienții de tratați cu CL între 1999 şi 2019 la un spital, de un medic specialist TGS şi între 2014 şi 2019 la alt spital, de alt medic specialist TGS. Criteriul de eligibilitate a fost CL efectuată de un chirurg TGS. Au fost excluse, din cauza absenței monitorizării, intervențiile efectuate de rezidenți şi la pacienți cu cancer de colecist. S-au raportat rezultatele pentru scurgeri de bilă, vătămări ale canalului biliar, sângerări, complicații de natură infecțioasă, vătămări ale intestinelor şi pseudoanevrisme, nevralgii, hernie incizională, hematom de mezenter, mortalitate sub 30 de zile şi conversie la intervenție deschisă. Pentru evaluarea diferențelor semnificative s-au utilizat teste statistice, cu interval de certitudine de $95 \%$ şi valoare $p<0,05$.

Rezultate: Cei doi chirurgi specialişti TGS au efectuat CL la 5122 
pacienți, din care 4396 (86\%) de sex feminin şi 715 (14\%) de sex masculin. Intervalul de vârste a fost 13-93 de ani, cu o medie de 48 de ani. 3681 (72 \%) intervenții au fost efectuate cu internare de o zi. $1431(28 \%)$ s-au efectuat cu internare, iar $287(5,6 \%)$ au fost CL de urgență. Nu s-au înregistrat decese în primele 30 de zile de la intervenție; s-au înregistrat $8(0,15 \%)$ scurgeri de bilă în canalul subvezical, 4 vătămări ale canalului biliar comun (CBC), $9(0,02 \%)$ conversii la intervenție deschisă şi $17(0,33 \%)$ intervenții abandonate. S-au identificat diferențe substanțiale între rezultatele studiului nostru şi cele din raportul CholeS.

Concluzii: Colecistectomia laparoscopică este caracterizată de rezultate acceptabile, risc redus de vătămare a canalului biliar şi mortalitate inexistentă dacă este efectuată de un chirurg specialist în chirurgia tractului gastrointestinal superior (TGS).

Cuvinte cheie: colecistectomie laparoscopică, specializare, complicații, tract gastrointestinal superior

\begin{abstract}
Background: Gallstone disease is a common problem and laparoscopic cholecystectomy (LC) is a common elective procedure. This operation was performed by a general surgeon, colorectal surgeons, breast and vascular surgeons according to the largest UK's audit (CholeS study).

Objectives: To compare the outcomes of laparoscopic cholecystectomy performed by a specialist upper gastrointestinal (UGI) surgeon to that of CholeS and large international studies. Our hypothesis is: UGI specialist is producing better outcomes for LC patients.

Methods: All patient who underwent LC between 1999 and 2019 at one hospital by an UGI consultant and 2014-2019 at another hospital by another UGI consultant surgeon were included. The inclusion criteria were LC performed by UGI surgeon. Lost to follow up, procedures done by trainees and gallbladder cancer patients were excluded. The outcome measures of bile leak, bile duct injuries, bleeding, infectious complications, bowel injuries, vascular injuries and pseudoaneurysms, neuralgia, port site hernia, mesenteric haematoma, 30-day mortality and conversion to open were reported. Statistical tests were used to assess the significant differences, the confidence interval was $95 \%$ and the p-value was taken as $<0.05$.

Results: Two UGI specialists performed 5122 LC, 4396 (86\%) were female and 715 (14\%) male. The age was 13-93 year (median of 48 years). 3681 (72\%) was done as a day surgery case. $1431(28 \%)$ as an inpatient and $287(5.6 \%)$ emergency LC. There was no death in the 30 days periods of surgery, $8(0.15 \%)$ biliary leak from the duct of Luschka, $4(0.19 \%)$ common bile duct (CBD) injuries, $9(0.02 \%)$ conversions and $17(0.33 \%)$ procedures were abandoned. There were significant differences in the above complications between our study and the CholeS report.

Conclusions: Laparoscopic cholecystectomy is associated with acceptable outcomes, low risk of bile duct injury and no mortality when performed by a specialist upper GI surgeon.
\end{abstract}

Key words: laparoscopic cholecystectomy, specialization, complications, Upper Gastro-intestinal

\section{Introduction}

Gallbladder (GB) disease is affecting $15 \%$ of the population, in which $20 \%$ are symptomatic, corresponding to a third of our emergency surgical admission. Emergency admissions due to biliary colic and acute cholecystitis are the two commonest presentations constituting more than $65 \%$ (1). Occasionally they may present directly with severe life-threatening empyema of the gallbladder, perforation, jaundice, pancreatitis and sepsis (2). Over the years, we noticed an increase in complicated presentation, possibly due to lifestyle, diet as 
well as the problems of accessing specialist care. As surgical management, LC is a common procedure in general surgery (3). However, some of its complications are life-changing and occurred between $0.5-0.6 \%$ (serious complication being bile duct injury $0.1-0.6 \%$ and major vessel injury $0.04-1.22 \%$ ) (4).

Subtotal cholecystectomy is an alternative choice in difficult cases reducing the incidence of injuries and provides a salvage to a complex case scenario $(5,6)$. There were different approaches to manage the difficult case, such as fundus first, use of intraoperative cholangiogram, indocyanine green fluoroscopy or subtotal LC $(7,8)$.

Specialisation of surgery has been the way forward in many different surgical specialities (cardiothoracic, paediatric, vascular) and the training is evolving towards earlier specialisation (Emergency Surgery, Breast, Endocrine, Upper and lower GI, transplant and HPB). In this new era of specialisation $(9,10), \mathrm{LC}$ is still performed by a general surgeon, colorectal surgeon, breast surgeon, vascular surgeons, hepatopancreatic biliary (HPB), oesophago-gastric (OG) and UGI across the hospitals in the UK $(1,11)$.

About $64 \%$ of litigations and medical negligence cases were due to the organ injuries incurred during LC resulted in a compensation cost of $£ 3.6$ million (12). Some bile duct injuries would need liver transplantation $(0.6 \%)$. Prediction of difficult LC was a useful tool to offer the patients the best surgical experience and reduce the risks and tragedy of severe avoidable complications (13). The LC is a common operation (about 60,000/year in the UK); the number of adverse outcomes is expected to be large. In the UK about 72-171 CBD injuries /year (the incidence between 0.16-0.25\%) (9).

Our hypothesis was the LC outcomes are better and organ injuries are less if the procedure performed by a specialist UGI surgeon.

This study aims to compare the outcomes of LC performed by UGI to that performed different surgical specialities in CholeS study.

\section{Methods}

\section{Study Design}

\section{Setting}

Data of all patients who underwent LC at two hospitals between 1999 and 2019 and 20142019 were included. Two consultants UGI surgeons performed the operations, collected and analysed the data. PRISMA flow chart was used (14) and STROBE statement was followed to conduct this study (15) (see Fig. 1).

\section{Definitions}

Upper GI specialist: Consultant surgeon who completed surgical training (CCST) in the UK, performing benign Upper GI surgery, emergency general surgery, endoscopy, not undertaking lower gastrointestinal (LGI) elective surgery and supported by endoscopic retrograde cholangiopancreatography (ERCP) and interventional radiology services.

First group: 4112 LC performed at one hospital by UGI surgeon during 1999-2019.

Second group: 1000 LC performed at another hospital by UGI surgeon during 2014-2019.

CholeS study: Largest UK audit of 8909 patients 2014-2016.

Emergency LC: LC that was performed within 3 days of presentation.

Subtotal LC: Excision of the body and fundus of the gallbladder leaving the stump /Hartman's pouch.

Fundus first LC: retrograde LC starting with fundus dissection.

\section{Participants, Inclusion and Exclusion Criteria}

The eligibility criteria are patients who underwent LC by an UGI surgeon. The exclusion criteria were the LC performed by trainees, other general, and lower GI consultant surgeons.

\section{Variables}

The important outcome measures were the bile duct injury and bile leak, the bleeding, organ injury, 30-day mortality and other 


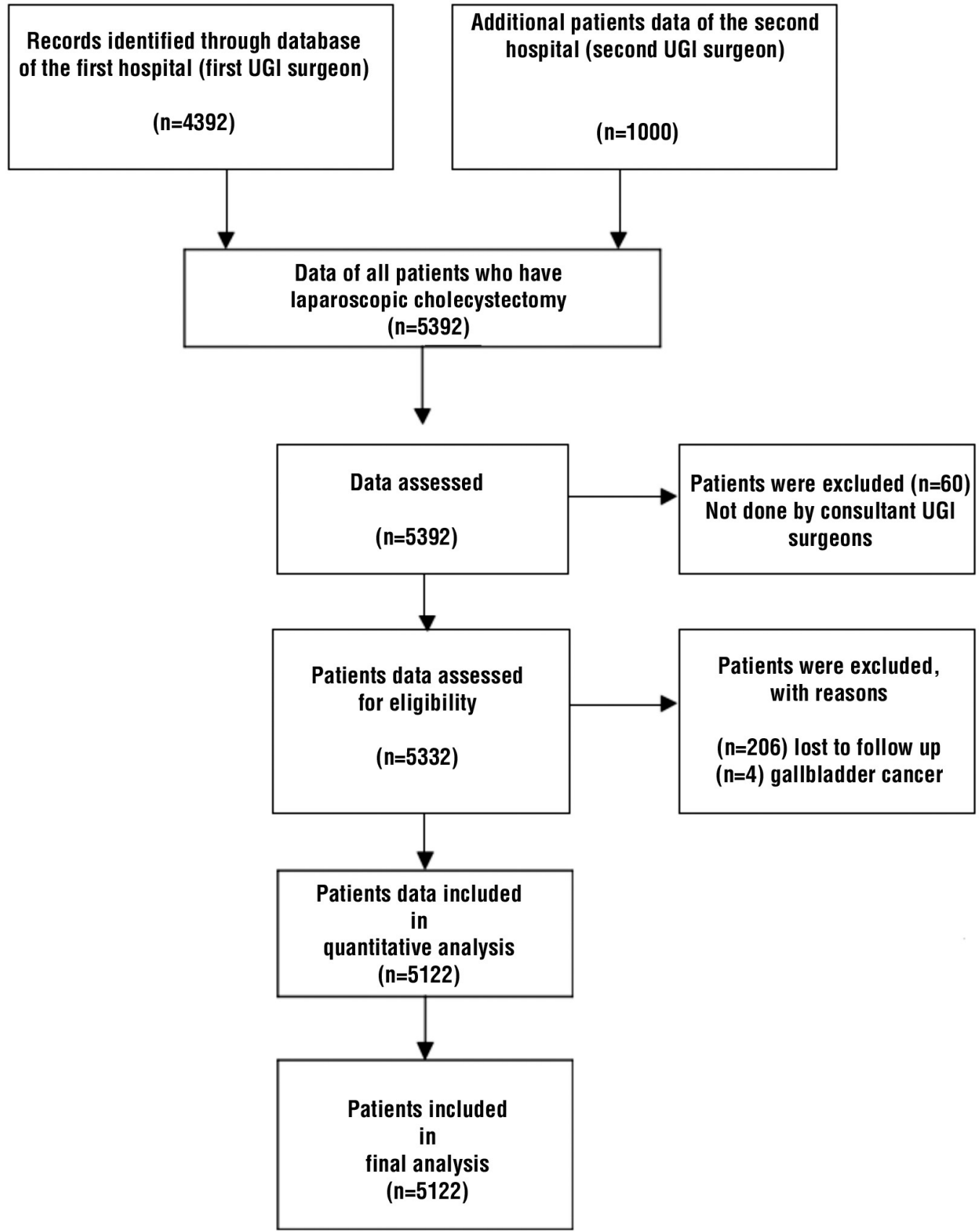

Figure 1. PRISMA flow chart

variables listed in Table 1. The potential confounders and effect modifiers were negligible as two specialist UGI surgeons at two different hospitals performed all operations. No age limit for patients and all consecutive patients were included.

\section{Data Sources/ Measurement}

The source of the data was the retrospectively collected details of patients, operations, follow up, complications and the outcomes on the hospital electronic systems (EPR, ICE, 
Table 1. Outcome measures of laparoscopic cholecystectomy, relative risk, relative risk reduction and management, the $p$-value for 4112 patients (first group)

\begin{tabular}{|c|c|c|c|c|c|c|c|c|}
\hline $\begin{array}{l}\text { Outcomes/ } \\
\text { characteristics }\end{array}$ & $\begin{array}{l}\text { No of } \\
\text { patients } \\
(\%)\end{array}$ & Management & $\begin{array}{c}\text { Relative risk, } \\
\text { RR \% }\end{array}$ & $\begin{array}{c}\text { Absolute risk } \\
\text { reduction } \\
\text { ARR\% }\end{array}$ & $\begin{array}{l}\text { Studies }^{3,14-23} \\
\text { Risk\% }\end{array}$ & $\begin{array}{l}\text { No to treat, } \\
\text { NTT }\end{array}$ & $\begin{array}{l}\text { Choles } \\
\text { study }^{21}\end{array}$ & P-value \\
\hline Day surgery & 2885 & & & & & & 5700 & $<00001$ \\
\hline Inpatient & 1237 & & & & & & 3209 & $<00001$ \\
\hline Death & 0 & - & 0 & 100 & 0.1 & 1000 & 11 & 0.024 \\
\hline Bile leak & $5(0.12 \%)$ & Surgery & 0.24 & 76 & 0.5 & 236 & 121 & $<00001$ \\
\hline CBD injury & $4(0.09 \%)$ & Surgery & $0.15-0.9$ & $10-85$ & $0.1-0.6$ & $125-333$ & 25 & 0.039 \\
\hline Bleeding & $1(0.02)$ & Surgery & $0.01-0.5$ & $50-99$ & $0.04-1.22$ & $83-500$ & 754 & $<00001$ \\
\hline Conversion & $9(0.2 \%)$ & To open surgery & 0.004 & 99.006 & 4.6 & 21 & 297 & $<00001$ \\
\hline Port site hernia & $11(0.2 \%)$ & Surgery & 0.11 & 99.89 & 1.7 & 66 & & \\
\hline Subhepatic abscess/collection & $5(0.1 \%)$ & Surgery/ drainage & 1 & 0 & 0.1 & 0 & 189 & $<00001$ \\
\hline Pseudoaneurysm & $2(0.04 \%)$ & Embolization & $0.16-0.32$ & $68-94$ & $0.25-0.5$ & $217-476$ & - & - \\
\hline Colonic injury & $2(0.04 \%)$ & Direct repair & 66 & 34 & $0.06-0.14$ & $500-1000$ & 49 & 0.004 \\
\hline Duodenal injury & $3(0.07 \%)$ & Direct repair & $28-66$ & $34-72$ & $0.06-0.14$ & $142-1000$ & 49 & 0.004 \\
\hline Subcostal neuralgia & $7(0.16 \%)$ & Pain management & 5 & 95 & 3 & 35 & - & - \\
\hline Mesenteric haematoma & $2(0.04 \%)$ & Conservative & 16 & 84 & 0.25 & 476 & - & - \\
\hline Superficial wound infection & $57(1 \%)$ & Drainage/antibiotics & 1 & 0 & 1 & 0 & 192 & 0.002 \\
\hline
\end{tabular}

Bluespier and Medsec) and the hard copies of the case notes. Two authors assessed the data for accuracy and social statistics (https://www. socscistatistics.com/) software and the excel data-analysis were used to calculate the significant differences.

\section{Bias}

There was no selection bias as all patients were included. There was a possibility of outcomes assessment bias as the post-operative follow up was conducted by the registrars in the surgical clinics, although they were not research team members, they were part of the surgical teams who performed the procedures. All patients with postoperative complications were admitted as emergency cases and were assessed by the on-call teams and were referred to the UGI specialists to manage. The UGI cover was $24 / 7$ rota.

\section{Study Size}

The study included a total of 5,112 (4,122 patients from the first hospital and 1000 patients from the second hospital) consecutive patients, this was considered a powerful cohort data compared to the previous reports (16-19).
For a margin of error of $5 \%$, confidence interval 95\%, Z-score of 1.96 and 50\% proportion, a sample of 385 was needed to show the statistical significance. The CholeS study included 8909 patients. Both studies outcomes were compared in the final analysis.

\section{Quantitative Variables}

1. Bile leak.

2. Bile duct injury.

3. Bleeding due to cystic artery, liver beds, omentum, abdominal wall and major vascular injury.

4. Conversion rate to open cholecystectomy (OC).

5. Port site hernia.

6. Subhepatic abscesses.

7. Pseudoaneurysm.

8. Colonic injury.

9. Duodenal injury.

10. Subcostal neuralgia.

11. Mesenteric haematoma.

12. Superficial wound infection/surgical site infection.

13. 30-day mortality.

The outcomes of these variables in two cohorts of patients were compared to the CholeS study, which is the most important UK 
Table 2. Outcome measures of laparoscopic cholecystectomy, relative risk, relative risk reduction and management, the p-value for 1000 patients (second group)

\begin{tabular}{|c|c|c|c|c|c|c|c|c|}
\hline Outcomes/characteristics & $\begin{array}{l}\text { No of patients } \\
(\%)\end{array}$ & Management & $\begin{array}{c}\text { Relative risk, } \\
\text { RR \% }\end{array}$ & $\begin{array}{c}\text { Absolute risk } \\
\text { reduction } \\
\text { ARR\% }\end{array}$ & $\begin{array}{l}\text { Literature }^{3,14-23} \\
\text { Risk \% }\end{array}$ & $\begin{array}{c}\text { No to treat, } \\
\text { NTT }\end{array}$ & $\begin{array}{l}\text { Choles } \\
\text { study21 }\end{array}$ & $P$ value \\
\hline Day surgery & 812 & & & & & & 5700 & $<0.00001$ \\
\hline Inpatient & 118 & & & & & & 3209 & $<0.00001$ \\
\hline Death & 0 & - & 0 & 100 & 0.1 & 1000 & 11 & 0.267 \\
\hline Bile leak & $5(0.5)$ & Surgery & 0.38 & 62 & 0.5 & 50 & 121 & 0.004 \\
\hline CBD injury & $0(0)$ & - & - & 100 & $0.1-0.6$ & 1000 & 25 & 0.092 \\
\hline Bleeding & $9(0.9)$ & - & - & 100 & $0.04-1.22$ & 1000 & 754 & 0.226 \\
\hline Conversion & $0(0)$ & - & - & 100 & 4.6 & 1000 & $297(3.3)$ & $<0.00001$ \\
\hline Port site hernia & $2(0.2)$ & Surgery & 0.11 & 99 & 1.7 & 66 & - & - \\
\hline \multicolumn{9}{|l|}{ Subhepatic abscess/ } \\
\hline Collections & $1(0.1 \%)$ & Surgery/ drainage & 1 & 0 & 0.1 & 10 & 189 & $<0.00001$ \\
\hline Pseudoaneurysm & $0(0)$ & - & - & 100 & $0.25-0.5$ & 1000 & - & - \\
\hline Colonic injury & $0(0)$ & - & - & 100 & $0.06-0.14$ & 1000 & 49 & 0.018 \\
\hline Duodenal injury & $0(0 \%)$ & - & - & 100 & $0.06-0.14$ & 1000 & 49 & 0.018 \\
\hline Subcostal neuralgia & $3(0.3 \%)$ & Pain management & 0.1 & 90 & 3 & 34 & - & - \\
\hline Mesenteric haematoma & $0(0 \%)$ & Conservative & - & 100 & 0.25 & 1000 & - & - \\
\hline Superficial wound infection & 19 & Drainage/antibiotics & 0.2 & 80 & 1 & 125 & 192 & 0.596 \\
\hline
\end{tabular}

report and also to other important literatures (3,14-23), see Table 1 and 2 .

The complications were classified according to the Clavien-Dindo system in both cohorts in Table 3.

\section{Statistical Methods}

Descriptive statistical methods were used for continuous parameters. Relative risk (RR) and absolute risk reduction (ARR) for outcomes measures were calculated for the study group, CholeS study and comparative literature. RR (relative risk) $=\mathrm{ART} / \mathrm{ARC}$. $\mathrm{ARR}$ (absolute risk reduction $)=\mathrm{ARC}-\mathrm{ART}(\mathrm{ARC}$ is the literature rate, ART is our study rate). Number to treat $(\mathrm{NNT})=1 / \mathrm{ARR}$.

The $\chi^{2}$ and $\mathrm{Z}$ statistics were used to compare the outcomes of each category of the two groups of patients to the outcomes of the UK's CholeS study (see Table 1 and 2). P-value was taken as $<0.05$ to confirm significance, $95 \%$ confidence interval.

Missing data: There was no missing data with regards to the outcome measures.

The follow-up: patients who developed

Table 3. Clavein-Dindo classification of complications for both groups

\begin{tabular}{|c|c|c|c|c|}
\hline Grade & Definition & $\begin{array}{l}\text { No(\%) } \\
\text { Hospital } 1 \\
4,112 \text { patients }\end{array}$ & $\begin{array}{l}\text { No(\%) } \\
\text { Hospital } 2 \\
1,000 \text { patients }\end{array}$ & P-value \\
\hline Grade I & $\begin{array}{l}\text { Deviation from the normal postoperative course. drugs as antiemetics, } \\
\text { antipyretics, analgesics, diuretics and electrolytes and physiotherapy }\end{array}$ & $35(31.8)$ & $19(48.7)$ & 0.058 \\
\hline Grade II & $\begin{array}{l}\text { Requiring pharmacological treatment with drugs other than such allowed } \\
\text { for grade I complications. Blood transfusions and total parenteral nutrition are also included. }\end{array}$ & $21(19)$ & $8(20.5)$ & 0.849 \\
\hline $\begin{array}{l}\text { Grade III } \\
\text { IIla } \\
\text { IIIb }\end{array}$ & $\begin{array}{l}\text { Requiring surgical, endoscopic or radiological intervention } \\
\text { Under LA } \\
\text { Under GA }\end{array}$ & $\begin{array}{l}15(13.6) \\
37(33.6)\end{array}$ & $\begin{array}{l}10(25) \\
3(7.7)\end{array}$ & $\begin{array}{l}0.085 \\
0.126\end{array}$ \\
\hline $\begin{array}{l}\text { Garde IV } \\
\text { IVa } \\
\text { IVb }\end{array}$ & $\begin{array}{l}\text { Life-threatening complication requiring IC/ICU-management } \\
\text { Single organ dysfunction (including dialysis) } \\
\text { Multiorgan dysfunction }\end{array}$ & $\begin{array}{l}02(1.8) \\
0\end{array}$ & $\begin{array}{l}0 \\
0\end{array}$ & $<0.0001$ \\
\hline Grade V & Death of a patient & 0 & 0 & - \\
\hline Total & & $110(2.6)$ & $39(3.9)$ & 0.0384 \\
\hline
\end{tabular}


major intra-operative or post-operative complications were managed at local hospitals. Two patients who had CBD injuries were referred to HPB centre after an appropriate initial management. All other patients who were fit for discharge were advised to attend the follow-up clinic in 6 weeks after the operation, and then they were discharged to their GPs unless they developed on going symptoms and or complications. For these patients, longer follows up and or second operations were arranged.

Patients who developed complications were referred by their GPs or presented to the A\&E department, the data of these patients were included in the final analysis. The loss to follow up: The data of these patients were not included in the final analysis.

\section{Local Gallstone Disease Management Policy}

All patients who were admitted as biliary colic, acute cholecystitis, empyema, perforated gallbladder and gangrenous cholecystitis were offered an emergency LC provided the history was less than 72 hours. If more than 72 hours, the patients were treated conservatively with antibiotics and or radiological cholecystostomy. We planned LC in 8 weeks for recovered patients. For gallstone pancreatitis, LC was arranged within 2 weeks of the pancreatitis onset as per National Institute for Care Excellence (NICE) guidelines. Patients who were referred by their GPs as a routine, scheduled to have an elective LC. Acute postoperative complications were managed by operating UGI surgeon (who did the first operation). The UGI specialist was available $24 / 7$.

Brief description of the LC technique: 4 ports (3 five $\mathrm{mm}$ ports plus one $10 \mathrm{~mm}$ port), pneumoperitoneum by Veress needle, and the pressure to $18-20 \mathrm{~mm}$ mercury. The Calot's triangle was dissected, critical view of safety was obtained, clipping and cutting the cystic duct and artery was performed, the gallbladder is dissected off the liver bed and removed, haemostasis was ensured and conclusion laparoscopy was performed to confirm no bile leak, bleeding or organ injury. All the ports were introduced under direct vision; the first port introduction was via visiport technique. When there was disturbed / abnormal anatomy, a per-operative cholangiogram or subtotal cholecystectomy was performed. The $10 \mathrm{~mm}$ port was closed at sheath level with PDS suture and skin with monocryl sutures. $20 \mathrm{mls}$ of $0.5 \%$ Marcaine was injected in the wounds.

\section{Results}

Participants: 5,122 patients were included in the final analysis (see Fig. 1).

\section{Descriptive Data}

In total, 5122 LC was conducted, 4396(86\%) were female and $715(14 \%)$ male. Their age was 13-93 years (median of 48 years). 3681 (72\%) LC was conducted as a day surgery case, while 1431 (28\%) LC as an inpatient and 287 (5.6\%) emergency LC. There was no death in the 30 days periods of surgery, $8(0.15 \%)$ biliary leak from the duct of Luschka, 4 (0.19\%) CBD injury, 9 (0.02\%) conversions and $17(0.33 \%)$ procedures were abandoned.

The risk reduction and relative risks were calculated for the remaining parameters (see Table 1, 2).

We performed $106(2 \%)$ subtotal LC and 20 $(0.39 \%) \mathrm{LC}$ as a two-stage procedure in which 6 were due to large fatty and rigid liver (for which we suggested liver shrinking diet for 4 weeks) and 10 cases were due to cholecystocolic fistula (needed to take bowel preparation before LC) and 4 due to suspicious cancer. Intraoperative cholangiogram was needed in $52(1 \%)$ patients.

For group one of 4112 operations, which were performed by first UGI specialist, there were $57(1 \%)$ superficial wound infection, $51(90 \%)$ of them at the gallbladder (GB) extraction port.

There were $11(0.2 \%)$ port-site incisional hernias, 5 (0.02\%) GB fossa abscess, 2 of them needed laparoscopic drainage, $2(0.04 \%)$ pseudoaneurysms following LC for perforated GB, presented on 5th postoperative day with 
bleeding from the drain and large collection. CT showed the right hepatic artery (RHA) pseudoaneurysm was managed by embolization. Another pseudoaneurysm was reported following LC for cholecysto-colic fistula. Presented with pain and managed by embolization.

$2(0.04 \%)$ colonic injuries and $3(0.07 \%)$ duodenal injuries were confirmed during difficult LC, all closed primarily with no postoperative problem but increased length of the stay.

$7(0.16 \%)$ subcostal neuralgia were managed by pain team after excluding abdominal com- $^{-}$ plications. $2(0.04 \%)$ mesenteric haematomata from Veress's needle injury was managed conservatively (see Table 1).

For group two of 1000 LC, there were 812 (81\%) day-case LC, $3(0.3 \%)$ bile leaks due to duct of Luschka (all were managed by laparoscopy and closure of the leak site using vicryl suturing) and two stump leaks were managed conservatively with drain and CBD stent, $3(0.3 \%)$ port site hernia (operated on), 3 (0.35) subhepatic abscesses were managed by radiological drainage, $3(0.3 \%)$ subcostal neuralgia were referred to the pain team after ruling out any abdominal complications, $21(0.2 \%)$ superficial port infections were managed by antibiotics/drainage and no mortality (see Table 2).

The complications were highlighted in table 3 using Clavien-Dindo system and there were no significant difference between two groups except for superficial infectious complications (20). The loss to follow up rate was $5 \%$ (206 patients).

\section{Discussion}

The most important findings of this large study were no single mortality in each of the two groups of patients after more than 5000 LC procedures. The UK's CholeS study of 8909 LC reported 11 (0.1\%)deaths (1). The Swedish Register for Cholecystectomy and ERCP reported $72(0.15 \%)$ deaths among $47912 \mathrm{LC}$ for gallstone disease (21). Another large population study confirmed overall mortality of $0.3 \%$ (176 deaths among 57,352 cholecystectomies) (22).

For group one of 4112 LC, There were significant differences in favour of this cohort in all measured variables except subcostal neuralgia, pseudoaneurysm and mesenteric hematomata that were not reported in CholeS study (21) (see Table 1, 2). There was no CBD injury or mortality reported in the second group, the trends were in favour of the 1000 LC group except for bleeding complications $\mathrm{p}$-value 0.226 .

The LC practice was varied across the UK. The CholeS study of 8,909 patients undergoing LC from 167 hospitals showed 1,451 (16.3 \%) LC was performed as an emergency, $4165(46.8 \%)$ as elective operations (21).

Both elective and emergency LC may be a challenging operation even in the expert hands.

It has been suggested an UGI specialist, was needed to perform emergency LC given the fact that complicated gallbladder was predicting higher morbidities and conversion rates $(23,24)$.

Our policy was to offer emergency LC for patients who present with biliary colic/acute cholecystitis within 3 days from the start of symptoms. Radiological percutaneous transhepatic drainage of the GB (cholecystostomy) was arranged for patients who presented after 3 days and were not responding to the conservative management to control the infection and schedule LC in 2-3 months. This approach was adopted by surgeons to safely manage acute and complicated cholecystitis (25).

The trends in LC practice was shifted towards day surgical case, the British Association of Day Surgery https://daysurgeryuk.net/en/home/ (BADS) recommended more than $60 \%$ of all LC would be done as day case (9). To achieve this, surgical time and the length of stay need to be reduced to a minimum. However, it has been shown that the achievement of these two goals is more likely to be produced by an experienced surgeon of high LC workload (24). We had achieved $72 \%$ of LC as day cases.

There was a need for admission for difficult 
cases, which can be predicted preoperatively.

Prediction of difficult LC is beneficial in planning the procedure, reducing the risks and minimising the cancellation on the day of operation. A recent report showed increasing age and ASA classification, male gender, diagnosis of CBD stone or cholecystitis, thickwalled gallbladders, CBD dilation, use of preoperative ERCP and non-elective operations were found to be significant independent predictors of difficult cases (25).

Less bile leak was reported when the surgery was performed by an UGI surgeons (26). Our leak rates were lower than the current literature $(0.19 \%$ versus $0.4 \%)$.

In our series, we have 8 patients who had a bile leak due to congenital duct of Luschka. All had uneventful LC. They presented 2-3 days following LC with sudden onset of abdominal pain. Laparoscopy revealed biliary peritonitis. In all cases, the leak was located in the middle part of the lower margin of the gallbladder bed, a common site of the duct of Luschka (30). The site of the leak was found in all cases and was sutured with vicryl. A drain was used in all cases. Only one patient had persistent bile leak with no clinical manifestation of peritonitis. It was not possible to insert a biliary stent during ERCP and this patient was treated conservatively. Four weeks later the bile leak dried and the drain was removed.

We had four cases of major bile duct injury (27) equivalent to a $10-85 \%$ risk reduction compared to the literature with incidence up to $0.5 \%(28-30)$. CholeS study reported 25 $(0.28 \%)$ CBD injuries. The relative risk was 0.32 and the risk reduction was equal to $68 \%$. This was a significant improvement in the incidence of CBD injuries.

We repaired the CBD injury and used a drain in the first patient. The second patient was treated by laparoscopic insertion of T-tube. The third case was complete transection of hepatic duct and needed hepaticojejunostomy at HPB centre. The fourth patient was diagnosed with a tumour of Hartmann's pouch and was treated by radical excision of the gallbladder at HPB centre.

The reduction of complication rate is also confirmed in different studies in which one of the factors is the surgical experience (31).

Reports showed specialisation reduce the risk of conversion to OC (32). Our conversion rate was $0.2 \%$ compared to $4.6 \%$ in the literature (33). There were a variety of reasons for conversion. One LC converted due to the severity of cholecystitis, there was uncontrollable bleeding from the omentum, which was adherent to the GB. Additional one conversion because of uncontrollable bleeding from the cystic artery. Six LC were converted due to intra-abdominal adhesion while one LC was converted because of GB bed bleeding that could not be controlled.

Port site hernia was reported in 11 patients $(0.2 \%)$. A recent review of 5,984 patients showed an overall incidence of port-site hernia was $1.7 \%$ (range, $0.3 \%$ to 5.4 ) while a large study of 5,541 laparoscopic operations confirmed $8(0.14 \%)$ hernias during a mean follow-up period of 43 months and required elective surgery for repair (34).

The subhepatic abscess was reported in 2 $(0.1 \%)$ patients. Powerful studies showed the same incidence after more than 9000 LC (35). The management of subhepatic abscess is mainly radiological drainage, however, we have drained two abscesses using laparoscopic approach.

The pseudoaneurysm was reported in 2 patients $(0.04 \%)$. The incidence of vascular injuries which predispose to pseudoaneurysm is $0.25-0.5 \% 36$. Trans-arterial embolization was used to manage the two cases.

Bowel injuries were reported after laparos-copic surgery with an incidence of about $0.13 \%$ (36). Gastrointestinal injuries may develop when operating on difficult or acutely inflamed GB.

We reported $2(0.04 \%)$ colonic and 3 $(0.07 \%)$ duodenal injuries .All cases were repaired immediately after recognition. The incidence after LC was $0.06 \%$ from a large Chinese study of more than 39,000 cases (37), however, it was a predictor of high mortality when associated with bile duct injuries (38). A study of 77,000 patients showed an incidence of $0.14 \%$ (39). 
Subcostal neuralgia was a rare complication after LC. It may be caused by inflammationinduced by port tract or injuries to the muscles and rib cage. Studies have shown a low but significant risk for development of chronic post-surgical pain after LC with an incidence between $3 \%$ and $56 \%(40,41)$.

The mesenteric haematoma was reported in $2(0.04 \%)$. It was a vascular injury to the mesenteric vessels induced by Veress's needle. The incidence of vascular injuries after LC is about $0.25 \%$ (36). These cases were usually managed conservatively.

Port site infection was reported in 57(1\%) patients. In a study of more than 30,000 patients, the incidence of infection was $1 \%$ (42). A recent report showed the incidence of $0.9 \%$ without antibiotics use compared to $3 \%$ with prophylactic antibiotics (43). We used intravenous $1.2 \mathrm{gm}$ of co-amoxiclav with induction in high-risk and patients with malnutrition. For penicillin allergy, gentamicin and metronidazole were used. Randomised controlled trial study suggested antibiotic prophylaxis is justified only in high-risk patients (44). Studies had shown the use of prophylactic antibiotics routinely is not decreasing the surgical site infection in LC (45).

LC was performed by different surgical specialities contrary to the ethos of the service specialisation. CholeS study showed that nonGI surgeons were still practising LC and it was unknown whether they meet the National Institute of Care Excellence (NICE) recommendation of 40 procedures per year.

\section{Limitations}

Our study had few limitations; the lost to follow up of $5 \%$ of patients may have an impact on the overall outcomes of this retrospective study.

There was no data on patients' comorbidities to perform subgroup analysis to validate the prediction scores for difficult procedures and to assess the degree of the complexity of cases. There was limited data on port site hernia following LC. There was a possibility of underreporting superficial infection that was treated by patients' general practitioners. There may also be under-reporting of other complications when patients presented to other hospitals or changed location after 6-12 weeks of the routine follow up.

\section{Conclusion}

In the UGI surgeon hands, laparoscopic cholecystectomy was associated with acceptable outcomes and low risk of bile duct injury and no mortality.

\section{Ethics of Approval}

Ethical approval was not needed for this retrospective study.

\section{Conflict of Interest}

Authors declare no conflict of interest.

Fund: no fund to support this study.

\section{References}

1. CholeS Study Group WMRC. Population-based cohort study of outcomes following cholecystectomy for benign gallbladder diseases. Br J Surg 2016; 103(12): 1704-15.

2. Karakayali FY, Akdur A, Kirnap M, Harman A, Ekici Y, Moray G. Emergency cholecystectomy vs percutaneous cholecystostomy plus delayed cholecystectomy for patients with acute cholecystitis. Hepatobiliary Pancreat Dis Int 2014; 13(3): 316-22.

3. Jara G, Rosciano J, Barrios W, et al. Laparoscopic subtotal cholecystectomy: a surgical alternative to reduce complications in complex cases. Cir Esp 2017; 95(8): 465-70.

4. Radunovic M, Lazovic R, Popovic N, et al. Complications of Laparoscopic Cholecystectomy: Our Experience from a Retrospective Analysis. Open Access Maced J Med Sci 2016; 4(4): 641-6.

5. Singhal T, Balakrishnan S, Hussain A, Nicholls J, Grandy-Smith S, El-Hasani S. Laparoscopic subtotal cholecystectomy: initial experience with laparoscopic management of difficult cholecystitis. Surgeon 2009; 7(5): 263-8.

6. Hussain A, El-Hasani S. The use of laparoscopic subtotal cholecystectomy for complicated cholelithiasis. Surg Endosc 2009; 23(4): 913.

7. Hussain A. Difficult laparoscopic cholecystectomy: current evidence and strategies of management. Surg Laparosc Endosc Percutan Tech 2011; 21(4): 211-7.

8. Ambe PC, Plambeck J, Fernandez-Jesberg V, Zarras K. The role of indocyanine green fluoroscopy for intraoperative bile duct visualization during laparoscopic cholecystectomy: an observational cohort study in 70 patients. Patient Saf Surg 2019; 13: 2 .

9. Borowski DW, Kelly SB, Bradburn DM, et al. Impact of surgeon volume and specialization on short-term outcomes in colorectal cancer surgery. Br J Surg 2007; 94(7): 880-9. 
10. Weitz J, Koch M, Friess H, Buchler MW. Impact of volume and specialization for cancer surgery. Dig Surg 2004; 21(4): 253-61.

11. Vohra RS, Spreadborough P, Johnstone M, et al. Protocol for a multicentre, prospective, population-based cohort study of variation in practice of cholecystectomy and surgical outcomes (The CholeS study). BMJ Open 2015; 5(1): e006399.

12. Roy PG, Soonawalla ZF, Grant HW. Medicolegal costs of bile duct injuries incurred during laparoscopic cholecystectomy. HPB (Oxford) 2009; 11(2): 130-4.

13. Nidoni R, Udachan TV, Sasnur P, Baloorkar R, Sindgikar V, Narasangi B. Predicting Difficult Laparoscopic Cholecystectomy Based on Clinicoradiological Assessment. J Clin Diagn Res 2015; 9(12): PC09-12

14. Liberati A, Altman DG, Tetzlaff J, et al. The PRISMA statement for reporting systematic reviews and meta-analyses of studies that evaluate health care interventions: explanation and elaboration. PLoS Med 2009; 6(7): e1000100.

15. von Elm E, Altman DG, Egger M, et al. Strengthening the Reporting of Observational Studies in Epidemiology (STROBE) statement: guidelines for reporting observational studies. BMJ 2007; 335(7624): 806-8.

16. Zhou J, Vithiananthan S. Risk factors for 30-day readmission and indication for ERCP following laparoscopic cholecystectomy: a retrospective NSQIP cohort study. Surg Endosc 2020.

17. Zang J, Yuan Y, Zhang C, Gao J. Elective laparoscopic cholecystectomy without intraoperative cholangiography: role of preoperative magnetic resonance cholangiopancreatography - a retrospective cohort study. BMC Surg 2016; 16(1): 45.

18. Zacks SL, Sandler RS, Rutledge R, Brown RS, Jr. A populationbased cohort study comparing laparoscopic cholecystectomy and open cholecystectomy. Am J Gastroenterol 2002; 97(2): 334-40.

19. Sanjay P, Weerakoon R, Shaikh IA, Bird T, Paily A, Yalamarthi S. A 5-year analysis of readmissions following elective laparoscopic cholecystectomy - cohort study. Int J Surg 2011; 9(1): 52-4.

20. Dindo D, Demartines N, Clavien PA. Classification of surgical complications: a new proposal with evaluation in a cohort of 6336 patients and results of a survey. Ann Surg 2004; 240(2): 205-13.

21. Sandblom G, Videhult P, Crona Guterstam Y, Svenner A, Sadr-Azodi 0 . Mortality after a cholecystectomy: a population-based study. HPB (Oxford) 2015; 17(3): 239-43.

22. Scollay JM, Mullen R, McPhillips G, Thompson AM. Mortality associated with the treatment of gallstone disease: a 10-year contemporary national experience. World J Surg 2011; 35(3): 643-7.

23. Ballal M, David G, Willmott S, Corless DJ, Deakin M, Slavin JP. Conversion after laparoscopic cholecystectomy in England. Surg Endosc 2009; 23(10): 2338-44.

24. Hobbs MS, Mai Q, Knuiman MW, Fletcher DR, Ridout SC. Surgeon experience and trends in intraoperative complications in laparoscopic cholecystectomy. Br J Surg 2006; 93(7): 844-53.

25. Nassar AHM, Hodson J, Ng HJ, et al. Predicting the difficult laparoscopic cholecystectomy: development and validation of a pre-operative risk score using an objective operative difficulty grading system. Surg Endosc 2019.

26. McKinley SK, Brunt LM, Schwaitzberg SD. Prevention of bile duct injury: the case for incorporating educational theories of expertise. Surg Endosc 2014; 28(12): 3385-91.

27. Lau WY, Lai EC. Classification of iatrogenic bile duct injury.
Hepatobiliary Pancreat Dis Int 2007; 6(5): 459-63.

28. Pandit N, Yadav TN, Awale L, Deo KB, Dhakal Y, Adhikary S. Current Scenario of Postcholecystectomy Bile Leak and Bile Duct Injury at a Tertiary Care Referral Centre of Nepal. Minim Invasive Surg 2020; 2020: 4382307

29. Seligman JY, Ragland JJ. Common bile duct injury after laparoscopic cholecystectomy: report of two cases. J Am Osteopath Assoc 1997; 97(4): 233-5.

30. Griffiths EA, Hodson J, Vohra RS, et al. Utilisation of an operative difficulty grading scale for laparoscopic cholecystectomy. Surg Endosc 2019; 33(1): 110-21.

31. Csikesz NG, Singla A, Murphy MM, Tseng JF, Shah SA. Surgeon volume metrics in laparoscopic cholecystectomy. Dig Dis Sci 2010; 55(8): 2398-405

32. Harrison EM, O'Neill S, Meurs TS, et al. Hospital volume and patient outcomes after cholecystectomy in Scotland: retrospective, national population based study. BMJ 2012; 344: e3330.

33. Frilling A, Li J, Weber F, et al. Major bile duct injuries after laparoscopic cholecystectomy: a tertiary center experience. J Gastrointest Surg 2004; 8(6): 679-85.

34. Hussain A, Mahmood H, Singhal T, Balakrishnan S, Nicholls J, ElHasani S. Long-term study of port-site incisional hernia after laparoscopic procedures. JSLS 2009; 13(3): 346-9.

35. Duca S, al-Hajjar N, Bala O, et al. [Mini invasive treatment of complications following laparoscopic cholecystectomy]. Chirurgia (Bucur) 2003; 98(5): 405-10.

36. Llarena NC, Shah AB, Milad MP. Bowel injury in gynecologic laparoscopy: a systematic review. Obstet Gynecol 2015; 125(6): 1407-17.

37. Huang $X$, Feng $Y$, Huang Z. Complications of laparoscopic cholecystectomy in China: an analysis of 39,238 cases. Chin Med J (Engl) 1997; 110(9): 704-6.

38. Gupta V, Gupta A, Yadav TD, Mittal BR, Kochhar R. Post-cholecystectomy acute injury: What can go wrong? Ann Hepatobiliary Pancreat Surg 2019; 23(2): 138-44.

39. Deziel DJ, Millikan KW, Economou SG, Doolas A, Ko ST, Airan MC. Complications of laparoscopic cholecystectomy: a national survey of 4,292 hospitals and an analysis of 77,604 cases. Am J Surg 1993; 165(1): 9-14.

40. Bisgaard T, Rosenberg J, Kehlet H. From acute to chronic pain after laparoscopic cholecystectomy: a prospective follow-up analysis. Scand J Gastroenterol 2005; 40(11): 1358-64.

41. Christoffersen MW, Brandt E, Oehlenschlager J, et al. No difference in incidence of port-site hernia and chronic pain after single-incision laparoscopic cholecystectomy versus conventional laparoscopic cholecystectomy: a nationwide prospective, matched cohort study. Surg Endosc 2015; 29(11): 3239-45.

42. Ely S, Rothenberg KA, Beattie G, Gologorsky RC, Huyser MR, Chang CK. Modern Elective Laparoscopic Cholecystectomy Carries Extremely Low Postoperative Infection Risk. J Surg Res 2020; 246 : 506-11.

43. Smith JP, Samra NS, Ballard DH, Moss JB, Griffen FD. Prophylactic Antibiotics for Elective Laparoscopic Cholecystectomy. Am Surg 2018; 84(4): 576-80.

44. Koc M, Zulfikaroglu B, Kece C, Ozalp N. A prospective randomized study of prophylactic antibiotics in elective laparoscopic cholecystectomy. Surg Endosc 2003; 17(11): 1716-8. 